\title{
PERMAINAN TRADISIONAL SEBAGAI SARANA MENGEMBANGKAN KEMAMPUAN FISIK MOTORIK ANAK DAN NILAI-NILAI PENDIDIKAN ISLAM DI PAUD KAMBOJA PROBOLINGGO
}

\author{
Nurul Widya Agustin \\ Ari Susandi \\ Devy Habibi Muhammad \\ Sekolah Tinggi Agama Islam Muhammadiyah Probolinggo \\ Email: widyawati.rara@gmail.com
}

\begin{abstract}
The goal of this research was to examine how traditional games can help Cambodian Probolinggo PAUD kids improve gross motor abilities while also teaching Islamic values. To address important issues, the author employs qualitative research methods such as observation, documentation, and interviews to gather data. In addition, data triangulation will be used to evaluate the information gathered (sources and techniques). One of the most important parts of an individual's total development is physical motor development. Traditional games have been shown to benefit children's gross motor nerves by requiring them to use their physical abilities in order to play. Traditional games can also be used as cultural heritage because people recognize that they are original games passed down from their forefathers and that they must be conserved so that they do not become extinct and forgotten. Traditional games help Cambodian Probolinggo PAUD children learn Islamic educational ideals. When the youngsters are at home, religious adherence and honesty are also indicators.
\end{abstract}

Keywords: Traditional Games, Physical Motoric Children, Islamic Educational Values

\section{Abstrak}

Penelitian ini bertujuan untuk mengkaji bagaimana permainan tradisional dapat membantu anak PAUD Kamboja Probolinggo meningkatkan kemampuan motorik kasar sekaligus mengajarkan nilai-nilai Islam. Untuk mengatasi masalah penting, penulis menggunakan metode penelitian kualitatif seperti observasi, dokumentasi, dan wawancara untuk mengumpulkan data. Selain itu, triangulasi data akan digunakan untuk mengevaluasi informasi yang dikumpulkan (sumber dan teknik). Salah satu bagian terpenting dari perkembangan total individu adalah perkembangan motorik fisik. Permainan tradisional telah terbukti bermanfaat bagi saraf motorik kasar anak-anak dengan mengharuskan mereka menggunakan kemampuan fisik mereka untuk bermain. Permainan tradisional juga dapat dijadikan sebagai warisan budaya karena masyarakat mengakui bahwa permainan tersebut merupakan permainan asli yang diturunkan dari nenek moyang dan harus dilestarikan agar tidak punah dan terlupakan. Permainan tradisional membantu anak-anak PAUD Kamboja Probolinggo mempelajari cita-cita pendidikan Islam. Ketika anak-anak berada di rumah, sinyalnya sama-sama religius dan jujur.

Kata Kunci : Permainan Tradisional, Fisik Motorik Anak, Nilai-Nilai Pendidikan Islam

\section{PENDAHULUAN}

Di negara Indonesia anak usia dini didefinisikan sebagai anak yang berumur 0 sampai 6 tahun, seperti yang ada pada UU Sisdiknas no. 20 tahun 2003 dijelaskan bahwa anak usia dini yaitu anak yang berumur 0 sampai 6 tahun. Yang diartikan sebagai anak yang tumbuh kembang sesuai dengan pertumbuhannya ${ }^{1}$.

\footnotetext{
1 Ai Sutini, Meningkatkan Keterampilan Motorik Anak Usia Dini Melalui Permainan Tradisional, (Cakrawala Dini: Jurnal Pendidikan Anak Usia Dini, Vol. 4 No. 2, November 2013), hal. 69

33 | Falasifa, Vol. 12 Nomor 2 September 2021
} 
Nurul Widya Agustin,

Ari Susandi,

Devy Habibi Mubammad

Pendidikan merupakan proses perubahan sikap dan tingkah laku seorang anak atau kelompok menjadi pribadi yang baik menjadi pembelajaran dan pelatihan. Manusia membutuhkan pendidikan sepanjang perkembangannya hingga dewasa, dimulai sejak usia muda ${ }^{2}$.Tahun-tahun awal pertumbuhan anak sangat penting, karena akan mempengaruhi kualitas masa depan mereka. Anak-anak adalah orangorang yang berbeda, unik, dan memiliki ciri-ciri yang berbeda berdasarkan fase perkembangan mereka. Sebab itulah, perkembangan pada anak usia dini bisa didapatkan melalui belajar dan bermain ${ }^{3}$. Maka dalam suatu pendidikan dibutuhkan adanya pola yang baik untuk perkembangan seorang anak ${ }^{4}$.

Bermain adalah salah satu hak anak dalam hidup; melalui bermain, anak-anak dapat belajar banyak hal yang tidak mereka ketahui sebelumnya. Anak-anak dapat belajar tentang dunia melalui bermain. Bermain adalah praktik yang tidak dapat ditinggalkan pada masa bayi karena memungkinkan anak-anak untuk bersenang-senang dan mengekspresikan diri secara bebas. Anak-anak adalah "pembelajar alami" karena mereka belajar paling baik ketika kegiatan dilakukan dalam lingkungan yang menyenangkan tanpa tekanan ${ }^{5}$.

Ada banyak permainan yang bisa dimainkan oleh anak-anak, salah satunya adalah permainan rakyat atau permainan tradisional. Permainan rakyat saat ini menyesuaikan dengan perkembangan zaman dan juga kemajuan teknologi. Banyak permainan tradisional yang ditinggalkan karena kemajuan teknologi yang pesat. Akibatnya, permainan tradisional diambang kepunahan, jika belum punah ${ }^{6}$.

Permainan tradisional merupakan warisan nenek moyang kita yang hampir punah pada zaman dahulu (mengalami kepunahan). Kepunahan ini disebabkan oleh kurangnya kesadaran publik, serta kemajuan teknis. Menurut tradisi, permainan tradisional ini juga merupakan hiburan yang menyenangkan di mana para pemainnya memiliki rasa kepuasan ketika berpartisipasi ${ }^{7}$.

Permainan tradisional memiliki ciri khas tersendiri yang membedakannya dengan permainan lainnya. Sebagai permulaan, permainan sering menggunakan peralatan atau fasilitas yang ditemukan di lingkungan daripada membelinya. Permainan tradisional yang mendominasi memiliki jumlah pemain yang banyak atau berorientasi komunal, yang merupakan kriteria kedua. Tidak heran jika hampir setiap

\footnotetext{
${ }^{2}$ Devy Habibi Muhammad (dkk), Pendidikan Anak Usia Dini Berbasis Psikologi Islam, Jurnal Pendidikan Islam Al-Ilmi, Vol. 4, No. 1, Mei 2021), hal. 26

${ }^{3}$ Uswatun Hasanah, Pengembangan Kemampuan Fisik Motorik

Melalui Permainan Tradisional Bagi Anak Usia Dini, (Jurnal Pendidikan Anak, Vol. 5 No. 1, Juni 2016), hal. 720

${ }^{4}$ Qurrota A'yuni, (dkk), Pola Pendidikan Agama Islam Pada Anak Korban Keluarga Broken Home, (Jurnal Imtiyaz, Vol. 5, No. 2, September 2021), hlm. 66

${ }^{5}$ Nurwahidah (dkk), Permainan Tradisional Sebagai Sarana Mengembangkan Kemampuan Fisik Motorik Anak Usia Dini, (PAUD Lectura: Jurnal Pendidikan Anak Usia Dini, Vol. 4 No. 2, April 2021), hal. 52

${ }^{6}$ Rina Wijayanti, Permainan Tradisional Sebagai Media Pengembangan Kemampuan Sosial Anak, (Cakrawala Dini: Jurnal Pendidikan Anak Usia Dini, Vol. 5 No. 1, Mei 2014), hal. 54

7 Ai Sutini, Meningkatkan Keterampilan Motorik Anak Usia Dini Melalui Permainan Tradisional, (Cakrawala Dini: Jurnal Pendidikan Anak Usia Dini, Vol. 4 No. 2, November 2013), hal. 71
}

Falasifa, Vol. 12 Nomor 2 September 2021 | 34 
permainan rakyat memiliki begitu banyak peserta. Sebab, selain menekankan kenikmatan bersama, game ini juga memiliki tujuan yang lebih dalam untuk mengasah kemampuan interaksi pemain (potensi interpersonal) $)^{8}$.

Pertumbuhan dan perkembangan fisik anak terkait dengan perkembangan fisik motoriknya. Anak-anak dapat melakukan latihan motorik fisik melalui gerakan terkoordinasi yang dibantu oleh lingkungan yang mendorong pemberian rangsangan karena ciri-ciri khusus mereka, seperti rasa ingin tahu yang tinggi dan keinginan untuk bereksperimen?

Perkembangan motorik akan lebih ideal terutama pada anak, jika lingkungan tempat tumbuh kembangnya mendorong mereka untuk bergerak bebas. Kegiatan di luar ruangan mungkin menjadi pilihan terbaik karena dapat membantu meningkatkan pertumbuhan otot. Jika anak melakukan aktivitas di dalam ruangan, memaksimalkan ruang dapat digunakan sebagai metode untuk memberikan ruang bebas bagi mereka untuk berlari, melompat, dan melatih seluruh tubuh mereka ${ }^{10}$

Melalui kegiatan bermain, hubungan antara keterampilan motorik dieksplorasi. Seperti yang dikatakan sebelumnya, gerakan motorik kasar adalah keterampilan yang membutuhkan koordinasi sebagian besar bagian tubuh anak. Gerakan motorik kasar berkembang ketika anak-anak memiliki koordinasi dan keseimbangan yang praktis seperti orang dewasa. Keterampilan motorik merupakan bakat yang memerlukan koordinasi bagian-bagian tubuh anak, seperti mata, gerak otot tangan dan kaki, saraf, dan rangka, agar dapat menyeimbangkan tubuh dan bermain dengan kelincahan dan kecepatan ${ }^{11}$.

Permainan tradisional dapat memberikan dan mengembangkan nilai-nilai Islam pada seorang anak di samping meningkatkan kemampuan motorik fisik mereka. Karena kurikulum sekolah menentukan tujuan pendidikan di sekolah. Menurut Wahjudin, kurikulum pendidikan nilai di sekolah harus memuat nilai, norma, budaya, dan kegiatan yang dapat membentuk anak menjadi manusia yang berkemampuan tinggi yang mampu maju ilmu pengetahuan dan teknologi, mandiri, dan berkepribadian yang baik ${ }^{12}$.

Permainan tradisional memiliki dampak yang signifikan terhadap perkembangan kehidupan anak. Permainan tradisional dapat memiliki manfaat dan tujuan bagi perkembangan anak usia dini,

\footnotetext{
${ }^{8}$ Rina Wijayanti, Permainan Tradisional Sebagai Media Pengembangan Kemampuan Sosial Anak, (Cakrawala Dini: Jurnal Pendidikan Anak Usia Dini, Vol. 5 No. 1, Mei 2014), hal. 56

${ }^{9}$ Rohyana Fitriani, Perkembangan Fisik Motorik Anak Usia Dini, (Jurnal Golden Age Hamzanwadi University, Vol. 3 No. 1 , Juni 2018), hal. 26

${ }^{10}$ Rohyana Fitriani, Perkembangan Fisik Motorik Anak Usia Dini, (Jurnal Golden Age Hamzanwadi University, Vol. 3 No. 1 , Juni 2018), hal. 27

${ }^{11}$ Amalia (dkk), Upaya Peningkatan Motorik Kasar Anak Usia Dini Melalui Permaianan Tradisional Gobak Sodor, (Prosiding Seminar Nasional Pendidikan STKIP Kusuma Negara II, 2020), hal. 165

${ }^{12}$ Afiful Ikhwan, Integrasi Pendidikan Islam

(Nilai-Nilai Islami Dalam Pembelajaran), (Ta'allum: Jurnal Pendidikan Islam, Vol. 2 No. 2, November 2014), hal. 181

35| Falasifa, Vol. 12 Nomor 2 September 2021
} 
Nurul Widya Agustin,

Ari Susandi,

Devy Habibi Mubammad

antara lain: 1) Anak belajar sportifitas; 2) Kemampuan fisik anak berkembang; dan 3) Kemampuan mental anak berkembang. 3) Lebih bersosialisasi, 4) Menggali Kreativitas, dan 5) Pahami Apa Artinya Berkolaborasi. 6) Meningkatkan percaya diri Anak 7) Belajar mengendalikan emosi. 8) Menanamkan rasa hormat pada anak, dan 9) belajar demokratis ${ }^{13}$.

Seperti yang telah dikemukakan sebelumnya, permainan tradisional memiliki peran dan pengaruh penting dalam merangsang tumbuh kembang anak. Maka, berdasarkan permasalahan penelitian yang dipaparkan pada latar belakang, maka penulis merumuskan masalah penelitian secara umum, yaitu Bagaimana peran permainan tradisional sebagai sarana pengembangan keterampilan motorik fisik pada anak usia dini di PAUD Kamboja Probolinggo dan Apa saja nilai-nilai pada permainan tradisional di PAUD Kamboja Probolinggo. Dan tujuan dari penelitian ini adalah untuk melihat apakah permainan tradisional berperan dalam perkembangan fisik motorik anak, serta untuk melihat nilai-nilai Islam apa yang ditanamkan dalam permainan tradisional. Kajian ini diharapkan dapat membuka jalan diskusi baru dalam komunitas ilmiah, khususnya bagi guru PAUD dan cendekiawan lainnya yang tertarik untuk belajar melalui permainan tradisional.

\section{PEMBAHASAN}

\section{Perkembangan Fisik Motorik Anak}

Orang sering menyamakan istilah perkembangan dan pertumbuhan. Sebenarnya, kedua kata ini pada dasarnya berbeda, meskipun mereka terhubung. Perubahan kuantitatif, seperti peningkatan ukuran dan struktur, diasosiasikan dengan pertumbuhan. Tangan, kaki, tubuh, otak, dan organ dalam lainnya seorang anak, misalnya, tumbuh dalam ukuran dan struktur di samping dimensi fisiknya. Proses pertumbuhan ini berkembang sepanjang hidupnya, namun laju pertumbuhan berubah tergantung pada usianya. Pertumnuhan ini berlanjut pada perkembangan yang sifatnya lebih kualitatif ${ }^{14}$.

Istilah "pembangunan" mengacu pada pergeseran kualitatif. Pengembangan diprioritaskan tidak hanya dari segi materi tetapi juga dari segi fungsionalitas. Lambat laun dan seiring berjalannya waktu, perkembangan terjadi. Akibatnya, perkembangan dapat digambarkan sebagai perubahan kualitatif dalam fungsi apa pun yang disebabkan oleh proses tumbuh dan belajar ${ }^{15}$.

Perkembangan pengendalian gerak fisik melalui tindakan yang terkoordinasi dari pusat saraf, saraf, dan otot disebut sebagai perkembangan motorik. Kekuatan ini berasal dari perkembangan

\footnotetext{
${ }^{13}$ Amalia (dkk), Upaya Peningkatan Motorik Kasar Anak Usia Dini Melalui Permaianan Tradisional Gobak Sodor, (Prosiding Seminar Nasional Pendidikan STKIP Kusuma Negara II, 2020), hal. 165

${ }^{14}$ Aghnaita, Perkembangan Fisik-Motorik. Anak. 4-5 Tabun Pada Permendikebud no. 137 Tahun 2014 (Kajian Konsep Perkembangan Anak), (Al-Athfal : Jurnal Pendidikan Anak, Vol. 3, No. 2, November 2017), hal. 224

${ }^{15}$ Aghnaita, Perkembangan Fisik-Motorik. Anak 4-5 Tabun Pada Permendikbud no. 137 Tahun 2014 (Kajian Konsep Perkembangan Anak), (Al-Athfal : Jurnal Pendidikan Anak, Vol. 3, No. 2, November 2017), hal. 225
}

Falasifa, Vol. 12 Nomor 2 September 2021 | 36 
introspeksi dan aktivitas massa, yang keduanya hadir sejak lahir. Kemampuan seorang anak untuk menggerakkan dan mengontrol bagian-bagian tubuh merupakan aspek terpenting dari perkembangan motorik $^{16}$.

Perkembangan motorik fisik sama pentingnya dengan bidang perkembangan lainnya, serta bisa dijadikan sebagai rujukan untuk ketentuan dalam pertumbuhan dan perkembangan anak. Hal ini karena perkembangan fisik motorik, seperti perubahan ukuran tubuh anak, dapat dengan mudah dideteksi menggunakan panca indera ${ }^{17}$.

Terdapat dua jenis perkembangan motorik yaitu perkembangan motorik kasar dan perkembangan motorik halus. Untuk memanjat, melompat, berlari, dan berpartisipasi dalam kegiatan di luar ruangan, anak-anak membutuhkan koordinasi kelompok di otot mereka serta koordinasi sebagian besar tubuh mereka menggunakan otot besar ${ }^{18}$.

\section{Faktor-Faktor yang Mempengaruhi Perkembangan dan pertumbuhan fisik Motorik Anak}

Dalam hal masalah fisik motorik, terdapat beberapa faktor yang mempengaruhi perkembangan dan pertumbuhan anak, diantaranya ${ }^{19}$;

a. Faktor yang diturunkan dari generasi ke generasi (keturunan) Penyakit fisik disebabkan oleh variabel dari keturunan karena mereka adalah produk dari satu keturunan yang diturunkan ke yang lain, meskipun mereka berasal dari keluarga jauh. Seperti tinggi badan, kecepatan, dan pertumbuhan.

b. Nutrisi dan Diet Sangat penting bagi orang tua untuk memberi makan anak-anak mereka makanan bergizi untuk memasok energi kepada anak-anak yang aktif di usia muda. Pemberian nutrisi atau nutrisi yang tepat dapat membantu pertumbuhan dan perkembangan organ tubuh manusia.

c. Faktor lingkungan yang baik atau merugikan kematangan fungsi- fungsi. Faktor Unsur lingkungan yang mempengaruhi kematangan fungsi secara positif atau negatif. Perkembangan kemampuan motorik anak sangat dipengaruhi oleh lingkungan sekitarnya. Jelas bahwa ada banyak tren pengasuhan anak di dunia, yang masing-masing memiliki dampak berbeda pada perkembangan fisik dan spiritual anak. Akibatnya, orang tua membangun suasana di mana anak-anak mereka dapat mengembangkan semua bagian perkembangan mereka, terutama kemampuan motorik mereka.

\footnotetext{
${ }^{16}$ Aghnaita, Perkembangan Fisik-Motorik Anak 4-5 Tabun Pada Permendikbud no. 137 Tabun 2014 (Kajian Konsep Perkembangan Anak), (Al-Athfal : Jurnal Pendidikan Anak, Vol. 3, No. 2, November 2017), hal. 225

${ }^{17}$ Rohyana Fitriani, Perkembangan Fisik Motorik Anak Usia Dini, (Jurnal Golden Age Hamzanwadi University, Vol. 3, No. 1, Juni 2018), hal. 31

${ }^{18}$ Heri Yusuf Muslihin, Bagaimana Mengajarkan Gerak Lokomotor Pada Anak Usia Dini?, Jurnal Paud Agapedia, Vol. 2, No. 1, Juni 2018), Hal. 83

${ }_{19}$ Adek Diah Saputri (dkk), Implementasi Permainan Tradisional Gobag Sodor Dalam Mengembangkan Motorik Kasar Anak Usia Dini Di Tk Pertiwi 2 Sidodadi Kecamatan Pekalongan Kabupaten Lampung Timur, (Kiddo: Jurnal Pendidikan Islam Anak Usia Dini, Vol. 2, No. 2, Agustus 2021), hal. 150
}

37| Falasifa, Vol. 12 Nomor 2 September 2021 
Nurul Widya Agustin,

Ari Susandi,

Dery Habibi Muhammad

d. Pola asuh yang baik, serta pandangan yang baik dari lingkungan dan masyarakat yang merangkul keberadaan anak, akan membantu anak mengembangkan konsep diri yang positif. Anak-anak membentuk opini tentang diri mereka sendiri berdasarkan apa yang mereka lihat dan pelajari di lingkungan mereka. Anak-anak diajarkan untuk bersikap objektif dan menghargai diri mereka sendiri dengan selalu berpikir positif tentang diri mereka sendiri ${ }^{20}$.

Kegiatan-kegiatan yang dapat membantu anak-anak dengan keterampilan motorik kasar mereka diantaranya yaitu ${ }^{21}$ :

1. Berjalan dalam berbagai gerakan.

2. Mencari jejak

3. Berjalanlah seolah-olah Anda adalah binatang.

4. Berjalan-jalan naik turun tangga.

5. Berbaris, melangkah, berjingkat, dan berjalan seperti kuda yang panik

6. Cepat naik turun seperti cambuk kuda,

7. Berjalan di tempat.

8. Melompat seperti kanguru di atas trampolin kecil.

9. Jalan-jalan di atas catwalk sambil membawa barang (bolak-balik dan menyamping),

10. Keluarkan potongan dari mangkuk dan letakkan di lokasi baru.

11. Melompat seperti katak,

12. Membuat terowongan.

\section{Jenis-jenis Permainan Tradisional}

Permainan tradisional merupakan permainan turun menurun yang diwariskan oleh nenek moyang sebagai produk yang mengandung nilai pendidikan dan budaya yang bisa menyenangkan hati orang yang bermain permainan tersebut ${ }^{22}$.

Berikut ini adalah contoh permainan tradisional ${ }^{23}$ :

1. Tebak, ketuk, congklak, lompat tali, dan engklek. Permainan ini dapat membantu anak-anak mengembangkan kemampuan fisik dan sosial mereka serta keterampilan logika dan fisika mereka, seperti berhitung.

\footnotetext{
${ }^{20}$ Jami'atul Muslimah (dkk), Pola Asuh Orang Tua danPerkembangan Moral Anak Usia Dini (Studi Kasus di TK Al-Ghazali Jl. Raya Nyalaran Kelurahan Kolpajung Kecamatan Pamekasan Kabupaten Pamekasan), (Kiddo: Jurnal Pendidikan Islam Anak Usia Dini, Vol. 1, No. 1, Februari 2020), hal. 7

${ }^{21}$ Ahmad farid Utsman (dkk), Peran Permainan Tradisional dalam Meningkatkan Motorik Kasar Anak Usia 5-6 Di RA Al Fattah Pacing Parengan Tuban, (Al Ulya : Jurnal Pendidikan Islam, Vol. 3, No. 2, Desember 2018), hal. 137

${ }^{22}$ Ulya Latifah dan Anita Chandra Dewi Sagala, Upaya Meningkatkan Interaksi Sosial Melalui Permainan Tradisional Jamuran Pada Anak Kelompok B Tk Kuncup Sari Semarang Tabun Pelajaran 2014/2015, (Jurnal Penelitian PAUDIA, 2015), Hal. 125

${ }^{23}$ Ahmad farid Utsman (dkk), Peran Permainan Tradisional dalam Meningkatkan Motorik Kasar Anak Usia 5-6 Di RA Al Fattah Pacing Parengan Tuban, (Al Ulya : Jurnal Pendidikan Islam, Vol. 3, No. 2, Desember 2018), hal. 138
}

Falasifa, Vol. 12 Nomor 2 September 2021 | 38 
2. Petak umpet, gobak sodor, dan benteng. Permainan ini masuk dalam kategori permainan olahraga.

3. Mobil-mobilan, egrang, bola sodok, takraw, dan calung termasuk yang paling populer. Karena anak-anak didorong untuk terlibat dengan lingkungan mereka, bentuk permainan ini akan membantu perkembangan kecerdasan alami pada anak-anak.

Adapun hal-hal yang mempengaruhi mood anak saat bermain, antara lain: Kesehatan adalah nomor satu, diikuti oleh kecerdasan, jenis kelamin, lingkungan, dan tingkat sosial ekonomi ${ }^{24}$.

\section{Peran Permainan Tradisional Dalam Mengembangkan Fisik Motorik Anak Usia Dini di PAUD Kamboja Probolinggo}

Berdasarkan hasil observasi dan wawancara dan data berupa dokumentasi, disimpulkan bahwa dalam pengembangan keterampilan fisik anak permainan tradisional sangat berperan dalam hal ini. Observasi dan wawancara penulis di lapangan mengungkapkan bahwa para orang tua sangat antusias mengajarkan permainan tradisional kepada anak-anak di PAUD Kamboja Probolinggo guna membantu mereka meningkatkan kemampuan fisik motoriknya. Ini dikarenakan adanya kegiatan yang sudah ada sangat berpengaruh terhadap pertumbuhan dan perkembanan anak baik dirumah ataupun lingkungan sekolah

Pada hasil observasi juga menunjukkan bahwa kemampuan motorik fisik anak sudah berkembang dengan baik. Hal ini dapat ditunjukkan dengan ketangkasan anak dalam memainkan permainan tradisional engkol bersama teman-temannya dengan tetap berpegang pada peraturan permainan yang telah ditetapkan. Karena permainan engklek tradisional merangsang gerakan anak dan meningkatkan koordinasi tubuh, membantu mereka mengembangkan kemampuan motorik kasar yang berguna dalam kehidupan sehari-hari. Kegiatan permainan tradisional engklek merupakan permainan yang dapat menarik minat anak-anak untuk melatih kesabaran, ketelitian, dan sikap disiplin. Keseimbangan, kelincahan, dan kecepatan adalah contoh keterampilan motorik kasar yang terlihat atau ditingkatkan dalam permainan.

Permainan tradisional terhadap perkembangan dan pertumbuhan anak bermanfaat dalam keseluruhannya, terutama komponen lahiriah dan bathiniyahnya. Melalui permainan tradisional, keterampilan yang berhubungan dengan fisik motorik anak dapat dipoles sesuai dengan yang telah diajarkan kepada anak. Siswa PAUD Kamboja Probolinggo dapat meningkatkan kemampuan motorik

\footnotetext{
${ }^{24}$ Ahmad farid Utsman (dkk), Peran Permainan Tradisional dalam Meningkatkan Motorik Kasar Anak Usia 5-6 Di RA Al Fattah Pacing Parengan Tuban, (Al Ulya : Jurnal Pendidikan Islam, Vol. 3, No. 2, Desember 2018), hal. 138
}

39| Falasifa, Vol. 12 Nomor 2 September 2021 
Nurul Widya Agustin,

Ari Susandi,

Devy Habibi Mubammad

kasarnya melalui stimulasi kegiatan tradisional sehingga dapat memenangkan kompetisi dalam aspek motorik kasar seperti:

1. Juara 2 lomba senam pinguin pada acara Gebyar Festival Paud antar sekolah se kecamatan Wonomerto tahun 2018.

2. Juara 1 menyusun balok pada acara Agustusan Antar sekolah se kec. Wonomerto tahun 2018.

3. Juara 3 Melompat satu kaki pada acara Agustusan Antar sekolah se kec. Wonomerto 2017.

4. Juara 2 lompat tali pada acara Agustusan Antar sekolah se kec. Wonomerto 2017.

Dengan prestasi anak-anak PAUD Kamboja Probolinggo tersebut di atas, menjelaskan bahwa adanya permainan tradisional mempunyai pengaruh positif dalam mengembangkan fisik motorik anak yang sangat besar. Sedangkan tujuan permainan tradisional, yaitu bertujuan untuk memberikan peningkatan dalam pengembengakan fisik motorik anak ${ }^{25}$.

Menurut informasi yang dihimpun, kegiatan perkembangan fisik motorik akan lebih menyenangkan jika dilaksanakan dalam bentuk permainan. Seperti contoh permainan engklek, yang bisa membuat anak senang mendorong anak untuk mengikuti aturan permainan, melatih koordinasi dan keseimbangan tubuh, serta meningkatkan kemampuan fisik mptorik anakdan permainan tradisional dapat membantu anak dalam hal berlari baik dalam hal ilncah dan cepatnya. Dan juga dapat merespon dengan cepat kebutuhan mereka, serta kemampuan lain, seperti keseimbangan, melalui perubahan atau adaptasi dalam permainan tradisional.

\section{Nilai-nilai pendidikan Islam pada permainan Tradisional di PAUD Kamboja Probolinggo}

Nilai-nilai Islam mendorong berbagai macam perilaku terpuji dalam kehidupan sehari-hari, yang semuanya dilakukan atas nama keridhaan Allah ${ }^{26}$. Ini dapat didefinisikan sebagai jenis perilaku yang menunjukkan keluhuran berdasarkan keyakinan kepada Tuhan dan rasa tanggung jawab untuk masa depan dalam keyakinan $\operatorname{Islam}^{27}$.

Menurut Kemendiknas beberapa tanda adanya nilai-nilai karakter pada permainan tradisional diantaranya : 1. Religius, 2. Kejujuran, 3. Toleransi, 4. Disiplin, 5. Usaha yang konsisten, 6. Kreatif 7. Mandiri, 8. Demokratis, 9. Kerja keras, 10. Semangat Kebangsaan, 11. Menghargai tanah air, 12. Menghargai Prestasi. 13. Ramah dan komunikatif 14. Cinta damai, 15. Gemar membaca, 16. Peduli dengan lingkungan, dan 17. Peduli dengan masalah sosial. 18. Tanggung jawab ${ }^{28}$.

\footnotetext{
${ }^{25}$ Ahmad farid Utsman (dkk), Peran Permainan Tradisional dalam Meningkatkan Motorik Kasar Anak Usia 5-6 Di RA Al Fattah Pacing Parengan Tuban, (Al Ulya : Jurnal Pendidikan Islam, Vol. 3, No. 2, Desember 2018), hal. 139

${ }^{26}$ Nur Kholis Madjid, Tradisi Islam: Peran dan Fungsinya dalam Pembangunan di Indonesia, (Jakarta:Paramadina,1997), hlm. 124

${ }^{27}$ Benny Prasetya, 9 pengembangan budaya religius di sekolah, (Jurnal Edukasi, Vol. 2, No. 1, Juni 2014), hlm. 476

${ }^{28}$ Mumuh Muhtarom, Nilai-Nilai Edukatif Dalam Permainan Tradisional Pada Masyarakat Lokal Di Sumedang, (Tatar Pasundan : Jurnal Diklat Keagamaan, Vol. 13, No. 1, Juni 2019), hlm. 56
} 
Sesuai dengan yang disebutkan diatas, diantara nilai-nilai karakter yang ada pada permainan tradisional yaitu religius dan kejujuran ${ }^{29}$. Dalam islam anak harus diajarkan tentang keagamaamn dan kejujuran sejak dini mungkin agar mereka bisa terbiasa untuk melakukakan hal-hal yang berhubungan dengan agama dan membiaskan diri mereka agar senantiasa jujur dalam kehidupan sehari-hari.

Hasil dari observasi dan wawancara kepada para pendidik dan wali murid tentang hal yang berkaitan dengan nilai-nilai islam yang berhubungan dengan agama dan kejujuran. Hal ini sudah dianggap mampu ditanamkan oleh para pendidik yang ada di PAUD Kamboja Probolinggo melalui permainan Tradisional. Seperti halnya berdoa sebelum memulai sesuatu, pada permainan tradisional anak-anak dituntut untuk berdo'a dulu sebelum memulai permainan. Hal ini bukan hanya berlangsung ketika di sekolah saja bahkan ketika di rumah pun anak mulai terbiasa memulai sesuatu yang lain dengan bero'a juga.

Selain masalah agama, dalam hal kejujuran pun pada permainan tradisional sangat mempengaruhi terhadap diri anak. Contoh seperti dalam permainan gobak sodor disitu seoarang anak dituntut untuk jujur dalam permainan tersebut. Ketika salah satu dari mereka ada yang tertangkap atau menyentuh terhadap lawannya maka disinilah kejujuran itu dibutuhkan. Dengan begitu anak akan mulai terbiasa untuk melakukan segala hal dengan jujur seperti ketika berbicara kepada orang tuanya.

Masalah mendasar dari penelitian ini adalah pentingnya permainan tradisional dan implementasinya di PAUD Kamboja Probolinggo yang diyakini bermanfaat bagi siswa, khususnya dalam pengembangan kemampuan motorik kasar. Penulis kemudian mengamati situasi nyata di lapangan sebagai akibat dari hal tersebut. Adakah kegiatan yang dapat digunakan lembaga PIAUD untuk merangsang kemampuan motorik kasar anak dengan mengajarkan permainan tradisional. Selain itu, permainan tradisional dapat digunakan untuk mengajarkan nilai-nilai Islam.

Hasil penelitian mengungkapkan bahwa: 1) Permainan tradisional berperan penting dalam meningkatkan motorik kasar anak PAUD Kamboja Probolinggo, terbukti dengan banyaknya prestasi yang diraih siswa PAUD tersebut pada festival dan lomba yang melibatkan motorik kasar anak; 2) Pendidik terus mengasah motorik kasar anak dengan terus menciptakan pembelajaran melalui permainan tradisional untuk meningkatkan motorik kasar anak secara berkelanjutan. 3) Permainan tradisional, seperti nilai agama dan kejujuran, memegang peranan penting dalam pengembangan nilainilai pendidikan Islam pada anak-anak di PAUD Kamboja Probolinggo.

\footnotetext{
${ }^{29}$ Ari Susandi (dkk), The Role Of Foster Parents In Implementing Character Education: Case Study of Children of Indonesian Workers in Puspan Village Maron District Probolinggo Regency, (CONCIENCIA: Journal of Islamic Education, Vol. 21, No. 1, Juni 2021), hlm 18
} 
Nurul Widya Agustin,

Ari Susandi,

Devy Habibi Mubammad

\section{KESIMPULAN}

Di PAUD Kamboja Probolinggo, fungsi permainan tradisional dalam perkembangan kemampuan fisik motorik anak berjalan dengan baik. Dan pengaruh atau peran tersebut sangat penting dalam mencapai berbagai kompetisi dan festival yang menuntut anak untuk menggunakan kemampuan motorik kasarnya.

Dengan banyaknya jenis permainan yang digunakan dalam permainan Tradisional, pendidik harus terus mengasah, mengembangkan, dan memelihara keterampilan motorik kasar anak. Pendidik juga harus memberikan Motivasi, dan penghargaan kepada anak didiknya.

Permainan tradisional memainkan peran penting dalam pengembangan nilai-nilai pendidikan Islam di kalangan anak-anak PAUD Kamboja Probolinggo. Demikian pula, ketika anak-anak berada di rumah, indikasinya memiliki kesesuaian dengan religius dan kejujuran.

\section{DAFTAR PUSTAKA}

Aghnaita, Aghnaita. "Perkembangan Fisik-Motorik Anak 4-5 Tahun Pada Permendikbud No. 137 Tahun 2014 (Kajian Konsep Perkembangan Anak)." Al-Athfal: Jurnal Pendidikan Anak 3, no. 2 (2017): 219. https://doi.org/10.14421/al-athfal.2017.32-09.

Amalia, Nur Afita, Tina Maharani, and Ilmi Noor Rahmad. “Upaya Peningkatan Motorik Kasar Anak Usia Dini Melalui Permaianan Tradisional Gobak Sodor.” Prosiding Seminar Nasional Pendidikan STKIP Kusuma Negara II, 2020, 162-72.

Fitriani, Rohyana. "Perkembangan Fisik Motorik Anak Usia Dini." Jurnal Golden Age 2, no. 01 (2018): 25-34. https://doi.org/10.29408/goldenage.v2i01.742.

Hasanah, Uswatun. "Pengembangan Kemampuan Fisik Motorik Melalui Permainan Tradisional Bagi Anak Usia Dini.” Jurnal Pendidikan Anak 5, no. 1 (2016): 717-33. https://doi.org/10.21831/jpa.v5i1.12368.

Ikhwan, Afiful. "Integrasi Pendidikan Islam (Nilai-Nilai Islami Dalam Pembelajaran)." Ta'allum: Jurnal Pendidikan Islam 2, no. 2 (2014). https://doi.org/10.21274/taalum.2014.2.02.179-194.

Jamiatul, Jamiatul, Muliatul Maghfiroh, and Ria Astuti. "Pola Asuh Orang Tua DanPerkembangan Moral Anak Usia Dini (Studi Kasus Di TK Al-Ghazali Jl. Raya Nyalaran Kelurahan Kolpajung Kecamatan Pamekasan Kabupaten Pamekasan)." Kiddo: Jurnal Pendidikan Islam Anak Usia Dini 1, no. 1 (2020): 1-9. https://doi.org/10.19105/kiddo.v1i1.2973.

Latifah, Ulya, and Anita Chandra Dewi Sagala. "Upaya Meningkatkan Interaksi Sosial Melalui Permainan Tradisional Jamuran Pada Anak Kelompok B Tk Kuncup Sari Semarang Tahun Pelajaran 2014/2015.” Penelitian PAUDLA, 2015, 112-32.

Madjid, Nurcholis. Tradisi Islam: Peran Dan Fungsinya Dalam Pembangunan Di Indonesia. Jakarta: Falasifa, Vol. 12 Nomor 2 September 2021 | 42 
Paramadina, 1997.

Maharany, Syafira, Nonik Kasiari, Wildani Firdaus, Jurusan Pendidikan, Agama Islam, Sekolah Tinggi, Agama Islam, and Kota Probolinggo. "POLA PENDIDIKAN AGAMA ISLAM PADA ANAK KORBAN KELUARGA BROKEN HOME.” Jurnal Imtiyaz 5, no. 02 (2021): 64-76.

Muhammad, Devy Habibi, Agustiarini Eka Deasari, and Aries Dirgayunita. "Pendidikan Anak Usia Dini Berbasis Psikologi Islam." Jumal Pendidikan Islam Al-Imi 4, no. 1 (2021): 21-33. https://doi.org/10.32529/al-ilmi.v4i1.821.

Muhtarom, Mumuh. "Nilai-Nilai Edukatif Dalam Permainan Tradisional Pada Masyarakat Lokal Di Sumedang." Tatar Pasundan: Jurnal Diklat Keagamaan 13, no. 1 (2019): 58-70. https://doi.org/10.38075/tp.v13i1.34.

Muslihin, Heri Yusuf. “Bagaimana Mengajarkan Gerak Lokomotor Pada Anak Usia Dini?” Jurnal Paud Agapedia 2, no. 1 (2020): 76-88. https://doi.org/10.17509/jpa.v2i1.24390.

Nurwahidah, Sri Maryati, Wulan Nurlaela, and Cahyana. "Permainan Tradisional Sebagai Sarana Mengembangkan Kemampuan Fisik Motorik Anak Usia Dini.” PAUD Lectura: Jurnal Pendidikan Anak Usia Dini 4, no. 02 (2021): 49-61. https://doi.org/10.31849/paud-lectura.v4i02.6422.

Prasetya, Benny. “9 Pengembangan Budaya Religius Di Sekolah.” Jurnal Edukasi 2, no. 1 (2014).

Saputri, Adek Diah. "Implementasi Permainan Tradisional Gobag Sodor Dalam Mengembangkan Motorik Kasar Anak Usia Dini Di Tk Pertiwi 2 Sidodadi Kecamatan Pekalongan Kabupaten Lampung Timur." Kiddo: Jurnal Pendidikan Islam Anak Usia Dini 2, no. 2 (2021): 143-53. https://doi.org/10.19105/kiddo.v2i2.4579.

Susandi, A., Ibnu, I., Salam, A., \& Arifin, M. (2021). THE ROLE OF FOSTER PARENTS IN IMPLEMENTING CHARACTER EDUCATION: Case Study of Children of Indonesian Workers in Puspan Village Maron District Probolinggo Regency. CONCIENCLA: Journal of Islamic Education, 21(1), 15-22.

Sutini, Ai. "Meningkatkan Keterampilan Motorik Anak Usia Dini Melalui Permainan Tradisional." Cakrawala Dini: Jurnal Pendidikan Anak Usia Dini 4, no. 2 (2018): 67-77. https://doi.org/10.17509/cd.v4i2.10386.

Utsman, Ahmad Farid, Roudlotun Ni'mah, and Rohana Rohana. "Peran Permainan Tradisional Dalam Meningkatkan Motorik Kasar Anak Usia 5-6 Di RA Al Fattah Pacing Parengan Tuban.” Al Ulya: Jurnal Pendidikan Islam 3, no. 2 (2018): 132-41. https://doi.org/10.36840/ulya.v3i2.156.

Wijayanti, Rina. "Permainan Tradisional Sebagai Media Pengembangan Kemampuan Sosial Anak." Cakrawala Dini: Jurnal Pendidikan Anak Usia Dini 5, no. 1 (2018): 51-56. 
Nurul Widya Agustin,

Ari Susandi,

Devy Habibi Mubammad

https://doi.org/10.17509/cd.v5i1.10496. 